\title{
Evaluation of the gastrointestinal parasite burden of goats in traditional breeding in Benin
}

Pierre Kétomon CHALLATON ( $\sim$ pierrechallaton@yahoo.fr)

Universite d'Abomey-Calavi Faculte des Sciences Agronomiques https://orcid.org/0000-0002-7251-5914

Guénolé Coovi Akouedegni

Universite d'Abomey-Calavi Faculte des Sciences Agronomiques

Cyrille Kadoéito Boko

Universite d'Abomey-Calavi

Géorcelin Goué Alowanou

Université Nationale des Sciences Technologies Ingénierie et Mathématiques: Universite Nationale des Sciences Technologies Ingenierie et Mathematiques

Venant Pascal Houndonougbo

Universite d'Abomey-Calavi Faculte des Sciences Agronomiques

Aboudou Habirou Kifouly

Universite d'Abomey-Calavi

Sylvie Mawulé Hounzangbe-Adote

Universite d'Abomey-Calavi Faculte des Sciences Agronomiques

\section{Research Article}

Keywords: Goats, breeding, gastrointestinal parasites, Benin

Posted Date: January 31st, 2022

DOI: https://doi.org/10.21203/rs.3.rs-1140439/v1

License: (c) (i) This work is licensed under a Creative Commons Attribution 4.0 International License. Read Full License 


\section{Abstract}

Goat farming in Benin is traditional. In this system, animals harbor parasites that cause economic losses related to growth and reproduction performance, which strongly affect farm productivity. The objective of this study was to evaluate the gastrointestinal parasite burden of goats in Benin. Thus, feces were sampled from 572 and 497 goats in the rainy and dry seasons, respectively, in southern, central and northern Benin. The parasite inventory was performed using the Mini-FLOTAC technique for the quantitative study and the Baermann method for the qualitative research. The results showed an overall prevalence of gastrointestinal parasites of $96.82 \%$. Furthermore, goats were mainly infected with Coccidia (92.24\%); strongyles (83.91\%), of which the critical genera were Haemonchus spp, Trichostrongylus spp, and Oesophagostomum spp; Strongyloides spp (73.25\%) followed by Moniezia spp (21.8\%). Other gastrointestinal parasites retrieved were Trichuris spp (0.94\%) and Toxocara spp (0.28\%). Infestation rates and the number of Eggs Per Gram of feces (EPG) were higher in the wet season than in the dry season. During the wet season, infestations were severe for strongyles, Moniezia spp, coccidian, and moderate for Strongyloides spp and light during the dry season except for Coccidia, where they were intense. Infestation rates and egg excretion of gastrointestinal parasites were shaped by age, sex, breed, and study areas. This knowledge of gastrointestinal parasites will help guide the surveillance of goat parasitosis in Benin.

\section{Introduction}

In Benin, goat farming is practiced throughout the country, with a national population in 2019 estimated at 1,955,811 heads (FAOSTAT, 2021). Highly adapted to the different agro-ecological conditions of Benin, goats are an essential source of meat products for urban and peri-urban markets. They are very present in the daily life of herders for savings, consumption, and ceremonies (Dossa et al. 2007). However, several constraints limit their productivity. Diseases in general, and more particularly parasitosis, are bottlenecks (Challaton, 2020). Thus, helminth diseases have been identified as limiting factors to expressing the productive potential (meat and milk) of goats (Wesongah et al. 2005). In tropical countries, gastrointestinal parasites are the most involved in these helminthiases of small ruminants (Githiori et al. 2004). Terefe et al. (2012) observed that the overwhelming majority of small ruminants in the tropics are infected with gastrointestinal parasites. In Benin, parasitological investigations on small ruminants revealed the presence of strongyle polyparasitism (Salifou, 1996). The prevalence rates of strongyles in small ruminants are high and vary between 4.4 and $92.6 \%$ (Salifou, 1996). A gastrointestinal (GI) parasite study carried out by Faihun et al. (2017) on small ruminants (sheep and goats) and a wild ruminant species (harnessed guib) revealed the presence of six parasites in sheep and goats (strongyles, Strongyloides, Coccidia, cestodes, Capillaria, and trematode) with rates ranging from 60 to $100 \%$. Salifou (1996) carried out a study in South Benin more than 14 years ago, and the most recent one was carried out in the riparian camps at the Wari-Mar classified forest by Faihun et al. (2017) in North-Benin were not exhaustive. Moreover, the previous study did not highlight the strongyles genera involved in gastrointestinal parasitosis of small ruminants.

According to Challaton (2020), the GI parasites treatment by farmers is based on synthetic chemical products. Nonotheless, Chartier et al. (2001) and Waller (2006), the ever-increasing and uncontrolled usage of chemical products are the leading cause of anti-parasites resistant issues.

However, since the 1970s, Benin has experienced pronounced climatic variations (Tidjani and Akponikpé, 2012), affecting ecosystems with an increased frequency of new infectious diseases (Gnanglè et al. 2011). Hence, farmers could face a high prevalence of gastrointestinal parasites. In addition, climatic variables can affect the prevalence, intensity, and geographical distribution of helminths, directly influencing the free-living larval stages and indirectly influencing mainly the hosts (Mas-Coma et al. 2008).

All this requires a new diagnosis by extending the studies to other country regions to identify the new species involved by focusing on goats to implement an effective and cost-efficient treatment plan in the farms. This diagnosis is the interest of this study which aims to evaluate the gastrointestinal parasite burden of goats in Benin.

\section{Materials And Methods}

\section{Study environment}

The studies were conducted in Benin. With an area of $114763 \mathrm{~km}^{2}$, Benin is located in West Africa between latitudes $6^{\circ} 10^{\prime} \mathrm{N}$ and $12^{\circ} 25^{\prime} \mathrm{N}$ and longitudes $0^{\circ} 45^{\prime} \mathrm{E}$ and $3^{\circ} 55^{\prime} \mathrm{E}$. The Atlantic Ocean borders Benin on the south, Togo on the west, Nigeria on the east, Niger on the northeast, and Burkina Faso on the northwest. Benin Republic has a tropical continental climate characterized by two seasons in the north (one rainy and one dry) and four seasons more or less marked in the south (two rainy and two dries). In terms of soil and flora, Benin is characterized by ten phytogeographical districts (PDs) and two major phytochorological regions separated by a transition zone. The Guineo-Congolian region with four PDs characterized by thickets and mangroves on sandy, hydromorphic and halomorphic soils, semideciduous forests on ferralitic and hydromorphic soils. Swamp forests also cover the latter. The Sudano-Guinean transition region with there PDs consisting of semideciduous forests, open forests, and gallery forests on ferritic grounds. Ferruginous soils on crystalline rocks support dry woods, open woodlands, and gallery forests in this zone. These formations are also present in the Sudanian zone on the same soil types (ferruginous soils on crystalline rocks). The Sudanian region with three PDs has ferruginous grounds on sedimentary rocks, savannahs, dry woods, and gallery forests. (Adomou et al. 2006; Aïtondji et al. 2016). In terms of agriculture, Benin is built around seven Agricultural Development Poles (PDAs). PDA1 covers the Niger Valley: an area of rice cultivation, flood plains, and lowlands. PDA2 covers Alibori (South), Borgou (North), and the 2KP (Kandi-Kouandé-Péhunco): this is the leading cotton area. The PDA3 considers Atacora (West), Borgou South, and Donga: an agricultural diversification zone (cotton and food products are grown there). PDA4 encompasses the mountain region (South Borgou, Donga, and mountain region) with cotton, food products, and cashew nuts as crops (diversification). Zou and Couffo represent PDA5: a zone dedicated to food crops. PDA6 is represented by the Plateau (specialized in agricultural diversification - oil palm and food products). PDA7 is made up of Ouémé, Atlantique, and Mono: a fishing and market gardening zone.

Goat feces were collected in PDAs 1, 2, 4, and 5 (Fig. 1) due to the concentration of livestock and the influence of goat breeds from neighboring countries on these areas. 
Coprological examinations were carried out at the Laboratory of Ethnopharmacology and Animal Health (LESA), located at the Faculty of Agronomic Sciences (FSA) of the University of Abomey-Calavi (UAC).

\section{Sampling period}

The first round of sampling was performed in the rainy season (August to October 2019) and a second one in the dry season (January to March 2020).

\section{Choice of farms and animals}

Nine (9) traditional farms were randomly selected in the communes of Malanville, Kandi, Gogounou, Kérou, Kouandé, Péhunco, Lalo, Klouékanmè, Zogbodomey Bohicon Djidja, Glazoué, Savè, Bantè, Parakou and N'Dali, divided into four PDAs (Fig. 1). The animals roam freely during the day while sharing the natural range. At night, most of them are reared in straw or tin-roofed pens, some of which are adjacent to the rooms. These shelters are also used to serve food supplements such as cassava peelings, soybean bran, millet bran, maize bran, and kitchen waste.

Animals over two months of age are eligible and were selected randomly from the sampled farms regardless of their general condition. All animals were tested for farms with less than six heads of goats, and six goats were sampled for farms with more than six heads. The age, sex, and breed of the tested animals were recorded.

\section{Feces collection}

For fecal collection, breeches were worn by the animals in night and were removed early the next day (Fig. 2). The feces in the breeches were collected in bags and labeled. The samples were then transported under cold-cover (mini dry icebox) to the Laboratory of Ethnopharmacology and Animal Health of the Faculty of Agronomic Sciences where they were immediately analyzed, or kept in the refrigerator at $+4^{\circ} \mathrm{C}$ for a maximum of two days to be diagnosed later. A total of 1069 fecal samples were taken from 572 and 497 goats, respectively, in the wet and dry seasons on 144 traditional farms per season. The difference in fecal samples is justified by the movement of animals within the farms during different seasons.

\section{Laboratory analysis}

\section{Quantitative coprology}

Quantitative coprology was performed by the Mini-Flotac technique (Cringoli et al. 2010) following standard operating procedures. The flotation fluid was a saturated solution of sodium chloride $(\mathrm{NaCl})$ of density $(\mathrm{d}=1.20)$. Two (02) grams of fresh fecal material was introduced into the Fill-Flotac vessel, and $18 \mathrm{ml}$ of $\mathrm{NaCl}$ of specific gravity 1.2 was added. The mixture's solution was then homogenized adequately with the Fill-Flotac homogenizing stick. The fecal suspension was then filtered through the Fill-Flotac and used to fill the two chambers of the Mini-Flotac. After 10 minutes, the upper part of the flotation chambers was translated and the Mini-Flotac ( $10 \times 40$ microscope). Fecal egg counts, expressed as the average number of eggs per gram of feces, were obtained by multiplying the total number of eggs by 5 . The identification of the parasite eggs was made based on the morphological characteristics described by Thienpont et al. (1995).

\section{Coproculture}

The study was completed by characterizing gastrointestinal strongyles encountered in each farm, coprocultures were performed for each farm. Fecal samples from individual farms were mixed and cultured at room temperature for ten days. The larvae were then extracted from the fecal mass using the Baermann device, which is based on the hygrotropism of the larvae. The coproculture was performed with feces from 288 goat farms (144 farms per season). Extracts from larval cultures were counted. One hundred (100) larvae were counted per sample and killed by the combined action of a $2 \%$ formaldehyde solution and heating at $55^{\circ} \mathrm{C}$. Larvae were collected and placed on a slide, and a drop of Lugol's solution was added to the transparent slide. Identification of the larvae was made under light microscopy at x10 and x40 magnification using the identification key described by Van Wyk and Mayhew (2013).

\section{Statistical analysis}

PDA was performed to determine the infestation rate of the animals, the rate of the type of infestation, and the parasites' prevalence; the infestation rate by parasite type were estimated using the formula:

$$
\text { Infestation rate }=\frac{\text { Number of positive samples } * 100}{\text { Total number of positive samples }}
$$

In addition, Pearson's Chi-squared test was performed to determine the influence of PDA, season, age, or breed on the infestation rate of the animals and the infestation rate of the farms by digestive strongyles. Finally, factorial correspondence analyses were performed to determine the distribution of these parasites according to PDA, sex age, and breed using the FactoMineR package of $\mathrm{R}$.

To study the variation of EPG with PDA and the degree of infestation of the farms with different strongyles species and to see if the season, age, sex, and breed influence EPG, means and standard errors were calculated. The effects of PDA and breed were identified using one-factor analysis of variance (ANOVA) with Tukey's post hoc test for the season, sex, and age; Student's t-test on independent data was used.

\section{Results}


After analyzing the fecal samples from goats ( $n=1069)$, the infestation rate of the animals was $96.82 \%$. The eggs observed belonged to nematodes, cestodes, and coccidia. Nematodes were represented by Strongyles (83.91\%), Strongyloides spp (73.25\%), whipworms (0.28\%) and Toxocara spp (0.28\%). Eggs of cestodes belonging to the genus Moniezia spp (21.8\%) were found as well as coccidian oocysts (Eimeria spp) (92.24\%). Fig. 3 shows the eggs of strongyles, Strongyloides spp and Moniezia spp. The parasite burden in terms of average EPG was $405.5 \pm 29.9$ for strongyles; $287.8 \pm 20.7$ for Strongyloides spp; $211 \pm$ 148 for Moniezia spp; $15 \pm 2.36$ for Trichuris spp; $16.67 \pm 3.33$ for Toxocara spp and $1984 \pm 138$ for coccidian oocysts (Table 1).

The main strongyles genera found in the fecal cultures were Haemonchus spp (98.95\%), Trichostrongylus spp (98.95\%), and Oesophagostomum spp (35.42\%) (Fig. 4). Fig. 5 shows the images of Haemonchus spp and Trichostrongylys spp larvae. The proportions of Haemonchus spp and Trichostrongylus spp larvae were significant in all seasons. The ratio of Haemonchus spp in the fecal samples in the dry season decreased and was dominated by Trichostrongylus spp (Table 2).

Table 1 Prevalence, mean EPG, and extreme egg shedding of gastrointestinal parasites

\begin{tabular}{|llll|}
\hline \multirow{2}{*}{ Parasites } & \multicolumn{3}{l}{ Fecal samples from goats $(\mathrm{n}=1069)$} \\
\cline { 2 - 4 } & Prevalence $(\%)$ & Mean EPG & EPG extremes \\
\hline Strongles & 83.91 & $405.5 \pm 29.9$ & $10-10080$ \\
\hline Strongyloides spp & 73.25 & $287.8 \pm 20.7$ & $10-6630$ \\
\hline Moniezia spp & 21.80 & $211 \pm 148$ & $5-34540$ \\
\hline Trichuris spp & 0.94 & $15 \pm 2.36$ & $5-25$ \\
\hline Toxocara spp & 0.28 & $16.67 \pm 3.33$ & $10-20$ \\
\hline Coccidian oocysts & 92.24 & $1984 \pm 138$ & $20-78500$ \\
\hline
\end{tabular}

EPG eggs per gram

Table 2 Intensity of strongyle larvae in fecal samples

\begin{tabular}{|lllll|}
\hline Variables & Overall average & Rainy season & Dry season & P-value \\
\hline Haemonchus spp & $44.7 \pm 1.07$ & $47.28 \pm 1.51$ & $42.12 \pm 1.52$ & 0.0162 \\
\hline Trichostrongylus spp & $40.23 \pm 1.07$ & $32.13 \pm 1.4$ & $48.32 \pm 1.51$ & $7.92 \mathrm{e}-14$ \\
\hline Oesophagostomum spp & $4 \pm 0.48$ & $4.51 \pm 0.83$ & $3.49 \pm 0.47$ & 0.29 \\
\hline Cooperia spp & $2.54 \pm 0.31$ & $2.05 \pm 0.36$ & $0.6 \pm 0.23$ & 0.000863 \\
\hline Nematodirus spp & $1.32 \pm 0.22$ & $2.37 \pm 0.4$ & $2.71 \pm 0.46$ & 0.588 \\
\hline Bunostomum spp & $0.54 \pm 0.19$ & $0.71 \pm 0.28$ & $0.37 \pm 0.27$ & 0.372 \\
\hline
\end{tabular}

\section{Zootechnical parameters influence the parasitic fauna}

The difference between Strongyles and Strongyloides spp infestation rate was significant in the rainy season $(p<0.0001)$. The EPG parasite burden was considerably higher in the wet season than in the dry season $(p<0.0001)$ for all three types of parasites $($ Table 3$)$.

Females were susceptible to undergo gastrointestinal parasites infestation than males. However, these differences were not significant ( $p>0.05)$. In addition, the prevalence of Strongyloides spp infestation was significantly higher in females than males $(P<0.05)$. In contrast, egg excretion of the parasites was higher in males (Table 4).

Age influenced the infestation rate and gastrointestinal parasite burden. In general, adults were the most infested with Strongyles, Strongyloides spp, Moniezia spp, and Coccidian oocysts with higher nematode EPG (Table 5).

The chi-square test showed that the breed of the animal had no influence on the infestation rate and parasite burden except for Strongyloides spp, where the infestation rate was significant $(p<0.05)$. However, the Sahelian breeds had higher infestation rates, but the EPG burden were lower than those of the other breeds. There was an absence of Toxocara spp and Trichuris spp eggs in the Metis (Dwarf Goat^Sahelian breed) and Sahelian breeds (Table 6).

Strongyles, Strongyloides spp, Moniezia spp, and coccidian oocysts infestation rates were significantly different between PDAs ( $p<0.0001)$ (Table 7, Figure 6). The discharge of parasite eggs was more significant in PDA4, the lack of Trichirus spp eggs in PDA1 and PDA5 and the absence of Toxocara spp eggs in PDA1 and PDA2 were observed (Table 7, Fig. 6).

Table 3 Effect of season on goat infestation and egg excretion of gastrointestinal parasites 


\begin{tabular}{|c|c|c|c|c|c|c|c|c|c|c|c|c|}
\hline \multirow[t]{2}{*}{ Season } & \multicolumn{2}{|l|}{ Strongyle } & \multicolumn{2}{|c|}{ Strongyloides spp } & \multicolumn{2}{|c|}{ Moniezia spp } & \multicolumn{2}{|c|}{ Trichuris spp } & \multicolumn{2}{|c|}{ Toxocara spp } & \multicolumn{2}{|c|}{ Coccidian oocysts } \\
\hline & Prevalence & $\begin{array}{l}\text { Mean } \\
\text { EPG }\end{array}$ & Prevalence & $\begin{array}{l}\text { Mean } \\
\text { EPG }\end{array}$ & Prevalence & $\begin{array}{l}\text { Mean } \\
\text { EPG }\end{array}$ & Prevalence & $\begin{array}{l}\text { Mean } \\
\text { EPG }\end{array}$ & Prevalence & $\begin{array}{l}\text { Mean } \\
\text { EPG }\end{array}$ & Prevalence & $\begin{array}{l}\text { Mean } \\
\text { EPG }\end{array}$ \\
\hline $\begin{array}{l}\text { Rainy } \\
(n=572)\end{array}$ & 88.81 & $\begin{array}{l}638.4 \\
\pm 50\end{array}$ & 85.49 & $\begin{array}{l}424 \\
\pm 31.4\end{array}$ & 11.19 & $\begin{array}{l}631 \pm \\
539\end{array}$ & 1.40 & $\begin{array}{l}16.25 \pm \\
2.8\end{array}$ & 0.52 & $\begin{array}{l}16.67 \\
\pm \\
3.33\end{array}$ & 93.36 & $\begin{array}{l}2798 \pm \\
230\end{array}$ \\
\hline $\begin{array}{l}\text { Dry } \\
(n=497)\end{array}$ & 78.27 & $\begin{array}{l}101.38 \\
\pm 7.76\end{array}$ & 59.15 & $\begin{array}{l}61.31 \\
\pm 4.67\end{array}$ & 34.00 & $\begin{array}{l}52.43 \\
\pm 7.75\end{array}$ & 0.40 & $10 \pm 0$ & 0.00 & & 90.95 & $\begin{array}{l}1022 \pm \\
116\end{array}$ \\
\hline Pvalue & $<0.0001$ & $\begin{array}{l}< \\
0.0001\end{array}$ & $<0.0001$ & $\begin{array}{l}< \\
0.0001\end{array}$ & $<0.0001$ & 0.2865 & 0.171 & 0.06043 & 0.2996 & & 0.1755 & $\begin{array}{l}< \\
0.0001\end{array}$ \\
\hline
\end{tabular}

EPG eggs per gram

Table 4 Effect of sex on goat infestation and egg excretion of gastrointestinal parasites

\begin{tabular}{|c|c|c|c|c|c|c|c|c|c|c|c|c|}
\hline \multirow[t]{2}{*}{ Sex } & \multicolumn{2}{|l|}{ Strongyles } & \multicolumn{2}{|c|}{ Strongyloides spp } & \multicolumn{2}{|c|}{ Moniezia spp } & \multicolumn{2}{|c|}{ Trichuris spp } & \multicolumn{2}{|c|}{ Toxocara spp } & \multicolumn{2}{|c|}{ Coccidian oocysts } \\
\hline & Prevalence & $\begin{array}{l}\text { Mean } \\
\text { EPG }\end{array}$ & Prevalence & $\begin{array}{l}\text { Mean } \\
\text { EPG }\end{array}$ & Prevalence & $\begin{array}{l}\text { Mean } \\
\text { EPG }\end{array}$ & Prevalence & $\begin{array}{l}\text { Mean } \\
\text { EPG }\end{array}$ & Prevalence & $\begin{array}{l}\text { Mean } \\
\text { EPG }\end{array}$ & Prevalence & $\begin{array}{l}\text { Mean } \\
\text { EPG }\end{array}$ \\
\hline $\begin{array}{l}\text { Female } \\
(n=750)\end{array}$ & 85.07 & $\begin{array}{l}391.9 \\
\pm 33.5\end{array}$ & 75.47 & $\begin{array}{l}277.4 \\
\pm 23\end{array}$ & 22.40 & $\begin{array}{l}53.87 \\
\pm \\
5.87\end{array}$ & 0.80 & $\begin{array}{l}15.63 \\
\pm 2.9\end{array}$ & 0.27 & $\begin{array}{l}15 \pm \\
5\end{array}$ & 92.48 & $\begin{array}{l}1726 \pm \\
156\end{array}$ \\
\hline $\begin{array}{l}\text { Male } \\
(n=319)\end{array}$ & 81.19 & $\begin{array}{l}439.5 \\
\pm 62.7\end{array}$ & 68.03 & $\begin{array}{l}315.2 \\
\pm 44.6\end{array}$ & 20.38 & $\begin{array}{l}619 \pm \\
530\end{array}$ & 1.25 & $\begin{array}{l}10.83 \\
\pm 0.83\end{array}$ & 0.31 & $\begin{array}{l}20 \pm \\
0\end{array}$ & 92.13 & $\begin{array}{l}2596 \pm \\
279\end{array}$ \\
\hline Pvalue & 0.137 & 0.5029 & 0.01471 & 0.4514 & 0.5141 & 0.291 & 0.7202 & 0.1505 & 1 & & 0.9466 & $0.00686 \epsilon$ \\
\hline
\end{tabular}

$E P G$ eggs per gram

Table 5 Effect of age on goat infestation and egg excretion of gastrointestinal parasites.

\begin{tabular}{|c|c|c|c|c|c|c|c|c|c|c|c|c|}
\hline \multirow[t]{2}{*}{ Category } & \multicolumn{2}{|l|}{ Strongyles } & \multicolumn{2}{|c|}{ Strongyloides spp } & \multicolumn{2}{|c|}{ Moniezia spp } & \multicolumn{2}{|l|}{ Trichuris spp } & \multicolumn{2}{|c|}{ Toxocara spp } & \multicolumn{2}{|c|}{ Coccidian oocysts } \\
\hline & Prevalence & $\begin{array}{l}\text { Mean } \\
\text { EPG }\end{array}$ & Prevalence & $\begin{array}{l}\text { Mean } \\
\text { EPG }\end{array}$ & Prevalence & $\begin{array}{l}\text { Mean } \\
\text { EPG }\end{array}$ & Prevalence & $\begin{array}{l}\text { Mean } \\
\text { EPG }\end{array}$ & Prevalence & $\begin{array}{l}\text { Mean } \\
\text { EPG }\end{array}$ & Prevalence & $\begin{array}{l}\text { Mear } \\
\text { EPG }\end{array}$ \\
\hline $\begin{array}{l}\text { Adult } \\
(n=560)\end{array}$ & 85.71 & $\begin{array}{l}451.4 \\
\pm 44\end{array}$ & 76.96 & $\begin{array}{l}315.3 \\
\pm 29.9\end{array}$ & 18.39 & $\begin{array}{l}54.17 \\
\pm 7.61\end{array}$ & 0.89 & $\begin{array}{l}17.14 \pm \\
2.86\end{array}$ & 0.18 & $20 \pm 0$ & 93.04 & $\begin{array}{l}2149 \\
190\end{array}$ \\
\hline $\begin{array}{l}\text { Young } \\
(n=509)\end{array}$ & 81.93 & $\begin{array}{l}352.7 \\
\pm 39.4\end{array}$ & 69.16 & $\begin{array}{l}254.1 \\
\pm 27.8\end{array}$ & 25.54 & $\begin{array}{l}336 \pm \\
265\end{array}$ & 0.98 & $\begin{array}{l}10 \pm \\
1.09\end{array}$ & 0.39 & 5 & 91.36 & $\begin{array}{l}1837 \\
199\end{array}$ \\
\hline Pvalue & 0.1095 & 0.0949 & 0.004933 & 0.1346 & 0.00591 & 0.2904 & 1 & 0.03068 & 0.934 & $>0.999$ & 0.3624 & 0.25 \\
\hline
\end{tabular}

EPG eggs per gram

Table 6 Effect of breed on goat infestation and egg excretion of gastrointestinal parasites

\begin{tabular}{|c|c|c|c|c|c|c|c|c|c|c|c|c|}
\hline \multirow[t]{2}{*}{ Breed } & \multicolumn{2}{|l|}{ Strongyles } & \multicolumn{2}{|c|}{ Strongyloides spp } & \multicolumn{2}{|c|}{ Moniezia spp } & \multicolumn{2}{|c|}{ Trichuris spp } & \multicolumn{2}{|c|}{ Toxocara spp } & \multicolumn{2}{|c|}{ Coccidian oocysts } \\
\hline & Prevalence & $\begin{array}{l}\text { Mean } \\
\text { EPG }\end{array}$ & Prevalence & $\begin{array}{l}\text { Mean } \\
\text { EPG }\end{array}$ & Prevalence & $\begin{array}{l}\text { Mean } \\
\text { EPG }\end{array}$ & Prevalence & $\begin{array}{l}\text { Mean } \\
\text { EPG }\end{array}$ & Prevalence & $\begin{array}{l}\text { Mean } \\
\text { EPG }\end{array}$ & Prevalence & $\begin{array}{l}\text { Mean } \\
\text { EPG }\end{array}$ \\
\hline $\begin{array}{l}\text { Dwarf } \\
\text { goat }(n=962)\end{array}$ & 83.16 & $\begin{array}{l}405.8 \\
\pm 31.8\end{array}$ & 74.01 & $\begin{array}{l}286 \pm \\
21.8\end{array}$ & 21.93 & $\begin{array}{l}222 \pm \\
164\end{array}$ & 1.04 & $\begin{array}{l}15 \pm \\
2.36\end{array}$ & 0.31 & $\begin{array}{l}16.67 \\
\pm \\
3.33\end{array}$ & 92.00 & $\begin{array}{l}1991 \\
\pm 147\end{array}$ \\
\hline $\begin{array}{l}\text { Dwarf } \\
\text { goat* Sahelian } \\
\text { breed }(n=64)\end{array}$ & 87.50 & $\begin{array}{l}424 \pm \\
113\end{array}$ & 59.38 & $\begin{array}{l}448 \pm \\
114\end{array}$ & 21.88 & $\begin{array}{l}152.5 \\
\pm \\
73.3\end{array}$ & 0.00 & & 0.00 & $\begin{array}{l}2198 \\
\pm 752\end{array}$ & 93.75 & $\begin{array}{l}2198 \\
\pm 752\end{array}$ \\
\hline $\begin{array}{l}\text { Sahelian goat } \\
(n=43)\end{array}$ & 95.35 & $\begin{array}{l}375 \pm \\
135\end{array}$ & 76.74 & $\begin{array}{l}142.1 \\
\pm 42.9\end{array}$ & 18.60 & $\begin{array}{l}23.75 \\
\pm \\
6.25\end{array}$ & 0.00 & & 0.00 & & 95.35 & $\begin{array}{l}1732 \\
\pm 415\end{array}$ \\
\hline Pvalue & 0.07505 & 0.965 & 0.0327 & 0.0821 & 0.8747 & 0.966 & 0.5704 & & 0.8459 & & 0.6492 & 0.859 \\
\hline
\end{tabular}

EPG eggs per gram

Table 7 Effect of PDA on goat infestation and egg excretion of gastrointestinal parasites 


\begin{tabular}{|c|c|c|c|c|c|c|c|c|c|c|c|c|}
\hline \multirow[t]{2}{*}{ PDA } & \multicolumn{2}{|l|}{ Strongyles } & \multicolumn{2}{|c|}{ Strongyloides spp } & \multicolumn{2}{|c|}{ Moniezia spp } & \multicolumn{2}{|c|}{ Trichuris spp } & \multicolumn{2}{|c|}{ Toxocara spp } & \multicolumn{2}{|c|}{ Coccidian oocysts } \\
\hline & Prevalence & $\begin{array}{l}\text { Mean } \\
\text { EPG }\end{array}$ & Prevalence & $\begin{array}{l}\text { Mean } \\
\text { EPG }\end{array}$ & Prevalence & $\begin{array}{l}\text { Mean } \\
\text { EPG }\end{array}$ & Prevalence & $\begin{array}{l}\text { Mean } \\
\text { EPG }\end{array}$ & Prevalence & $\begin{array}{l}\text { Mean } \\
\text { EPG }\end{array}$ & Prevalence & $\begin{array}{l}\text { Mean } \\
\text { EPG }\end{array}$ \\
\hline $\begin{array}{l}\text { PDA1 } \\
(n=43)\end{array}$ & 95.35 & $\begin{array}{l}375 \pm \\
135\end{array}$ & 76.74 & $\begin{array}{l}142.1 \\
\pm 42.9\end{array}$ & 18.60 & $\begin{array}{l}23.75 \\
\pm \\
6.25\end{array}$ & 0.00 & & 0.00 & & 95.35 & $\begin{array}{l}2198 \\
\pm 752\end{array}$ \\
\hline $\begin{array}{l}\text { PDA2 } \\
(n=283)\end{array}$ & 78.09 & $\begin{array}{l}415.7 \pm \\
67.7\end{array}$ & 63.25 & $\begin{array}{l}242.6 \\
\pm 41.7\end{array}$ & 33.57 & $\begin{array}{l}75.1 \\
\pm \\
10.6\end{array}$ & 1.06 & $\begin{array}{l}10 \pm \\
0\end{array}$ & 0.00 & & 89.75 & $\begin{array}{l}2207 \\
\pm 358\end{array}$ \\
\hline $\begin{array}{l}\text { PDA4 } \\
(n=416)\end{array}$ & 80.05 & $\begin{array}{l}523.4 \pm \\
61.5\end{array}$ & 69.23 & $\begin{array}{l}421.4 \\
\pm 44.4\end{array}$ & 14.18 & $\begin{array}{l}652 \pm \\
584\end{array}$ & 1.68 & $\begin{array}{l}17.17 \\
\pm \\
3.06\end{array}$ & 0.24 & $\begin{array}{l}20 \pm \\
0\end{array}$ & 87.98 & $\begin{array}{l}2014 \\
\pm 201\end{array}$ \\
\hline $\begin{array}{l}\text { PDA5 } \\
(n=327)\end{array}$ & 92.35 & $\begin{array}{l}272.3 \pm \\
20\end{array}$ & 86.54 & $\begin{array}{l}197.5 \\
\pm 20.2\end{array}$ & 21.71 & $\begin{array}{l}48.9 \\
\pm \\
15.4\end{array}$ & 0.00 & & 0.61 & $\begin{array}{l}15 \pm \\
5\end{array}$ & 99.39 & $\begin{array}{l}1749 \\
\pm 194\end{array}$ \\
\hline Pvalue & $<0.0001$ & 0.00555 & $<0.0001$ & $\begin{array}{l}< \\
0.0001\end{array}$ & $<0.0001$ & 0.393 & 0.1093 & 0.178 & 0.5277 & 0.667 & $<0.0001$ & 0.628 \\
\hline
\end{tabular}

PDA i Agricultural Development Pole

\section{Distribution of identified parasites within gender-age}

Correspondence Factor Analysis (CFA) results revealed that the three factorial axes summarize $79.85 \%, 12.98 \%, 7.17 \%$ distribution of parasite species within sex-age, respectively (Table 8). Strongyles, Strongyloides spp, Moniezia spp, and Coccidian Oocysts were much more characteristic of sex age. Toxocara spp and Trichirus spp affected goats less regardless of sex age (Fig. 7).

Table 8 Eigenvalues, percent variability, cumulative percent variability explained by factorial axes for sex-age

\begin{tabular}{|llll} 
& Eigenvalue & Percentage of variability & Cumulative percentage of variability \\
\hline $\operatorname{dim} 1$ & 0.0052035625 & 79.853179 & 79.85318 \\
\hline $\operatorname{dim} 2$ & 0.0008456422 & 12.977112 & 92.83029 \\
$\operatorname{dim} 3$ & 0.0004672078 & 7.169709 & 100 \\
\hline
\end{tabular}

Distribution of parasites identified according to the PDA

CFA results showed that the three factorial axes summarize $77.26 \%, 20.96 \%, 1.78 \%$ of the distribution of parasite species in the PDAs, respectively (Table 9 ). Strongyles, Strongyloides spp, Moniezia spp, and Coccidian Oocysts were much more characteristic of all PDAs. Toxocara spp and Trichirus spp species affected goats more miniature regardless of PDA (Fig. 8).

Table 9 Eigenvalues, percent variability, cumulative percent variability explained by factorial axes for PDA

\begin{tabular}{llll} 
& Eigenvalue & Percentage of variability & Cumulative percentage of variability \\
\hline $\operatorname{dim} 1$ & 0.0114623104 & 77.260199 & 77.26020 \\
\hline $\operatorname{dim} 2$ & 0.0031096776 & 20.960374 & 98.22057 \\
\hline $\operatorname{dim} 3$ & 0.0002639954 & 1.779426 & 100
\end{tabular}

\section{Species based parasites distribution}

CFA outcome showed that the two factorial axes summarize $80.48 \%, 19.52 \%$ distribution of parasite species between breeds, respectively (Table 10 ). Strongyles, Strongyloides spp, Moniezia spp, and Coccidian Oocysts were much more characteristic of all breeds. Toxocara spp and Trichirus spp affected goats regardless of the species bred (Fig. 9).

Table 10 Eigenvalues, percent variability, cumulative percent variability explained by factorial axes for the breed

\begin{tabular}{|llll} 
& Eigenvalue & Percentage of variability & Cumulative percentage of variability \\
\hline $\operatorname{dim} 1$ & 0.001075577 & 80.47648 & 80.47640 \\
\hline $\operatorname{dim} 2$ & 0.000260934 & 19.52352 & 100
\end{tabular}

\section{Discussion}


This study identified the different gastrointestinal parasites in traditional goat farms in Benin and evaluated their prevalence and parasite intensity in Eggs Per Gram of feces (EPG).

The high parasitism rate $(96.82 \%)$ can be explained on the one hand by the traditional type of farming where animals are free and share the same grazing area and, on the other hand, by the lack of routine deworming. Similar prevalences have been reported by Salifou (1996) in Benin, Sylvia et al. (2015) in Nigeria, Ntonifor et al. (2013) in Cameroon in goats farming. The main parasites observed during this study except toxocara spp had been previously reported in small ruminants in South Benin (Salifou 1996) and the riparian camps at the Wari-Maro classified forest in North Benin (Faihun et al. 2017).

The high prevalence of coccidian oocysts, strongyles, and Strongyloides spp could be attributable to their life cycle. $L_{3}$ larvae are the causative agent of the parasitic infestation. These L3 larvae undergo an automatic translation of the feces towards the grass. On the other hand, the cestodes found (Moniezia) have an obligatory intermediate host represented by certain arthropods that harbor the cysticercoid larvae. The contamination of animals requires prior ingestion of these infected arthropods. This outcome could justify that the infestation of animals by natural cycle and monoxenous parasites would be more frequent than that by parasites with an obligatory intermediate host. Furthermore, the low prevalence of whipworms among nematodes could be related to the fact that it is the embryonated egg containing the $L_{3}$ larva that is the infesting form of this parasite.

Similar observations for the highest prevalences of Strongyles, Strongyloides spp or coccidial oocysts in small ruminant farms, have also been made in most tropical countries, in Middle Guinea (Barry et al. 2002), Côte d'Ivoire (Achi et al. 2003), Togo (Bastiaensen et al. 2003), Ethiopia (Dagnachew et al. 2011), Burkina Faso (Ye 2012), Cameroon (Ntonifor et al. 2013), India (Dixit et al. 2016), Nigeria (Paul et al. 2016), Laos (Gueguen et al. 2016).

Prevalences of nematodes, as well as fecal egg excretion, are significantly higher in the rainy season. Similar observations had already been made in southern Benin by Salifou (1996) and in neighboring countries, Burkina Faso (Ouattara and Dorchies 2001), and Togo (Bastiaensen et al. 2003). According to Nwosu et al. (2007), environmental conditions are generally favorable for developing, survival, and translocation of pre-parasitic stages of parasitic nematodes during the rainy season. As a result, there is an accumulation of adult worm populations in grazing animals such that maximum worm burden are recorded during the rainy season. After that, worm populations decrease in the dry season. This funding justifies a higher prevalence of animal infestation and levels of parasite egg excretion in the wet season than in the dry season. The high prevalence rates of gastrointestinal parasites observed in this study indicate the risks of economic losses for goat farmers in Benin.

The mean degrees of infestation in animals were $638.4 ; 424 ; 631 ; 2798$ EPG in the rainy season and $101.38 ; 61.31 ; 52.43 ; 1022$ EPG in the dry season for strongyles, Strongyloides spp, Moniezia spp, and Coccidia Coccidian oocysts, respectively. According to the severity scales, based on the EPG limits revealed by Alowanou et al. (2021), it could be concluded that infestations were severe during the rainy season for strongyles, Moniezia spp, Coccidia oocysts and moderate for Strongyloides spp. During the dry season, infestations were light for strongyles, Strongyloides spp, Moniezia spp, and severe for Coccidia. This present case requires systematic deworming of all animals in the herd for according to Bosco (2014), an infestation rate above 200 EPG already requires treatment when the fecal analysis technique is Mini-FLOTAC.

Moreover, egg production still has no relation to the population of worms harbored, as many factors influence the EPG value. Thus, an animal may only host male worms or even adults who have not yet reached sexual maturity or worms whose females are in oviposition inhibition conditions (Salifou 1996). This result shows that the animals would be heavily parasitized.

Sex had no statically significant effect on infestation with gastrointestinal parasites except Strongyloides sp. However, on all the animals studied, the proportion of females affected by nematodes was higher than males. This observation is in opposite of the conclusion of Tariq et al. (2010) who revead that both sexes are susceptible to nematode infestation. During the peripartum period, females temporarily lose their naturally acquired immunity to gastrointestinal parasites (Schoenian 2012), and therefore, they could be easily infected. Thus the slight differences in prevalence observed in females could be due to pregnant and breast-feeder females among the females sampled in this study.

The parasites prevalence and egg excretion level by age showed that adult animals were more infected with gastrointestinal nematodes than the young animales. This observation is not in agreement with the findings of some authors for whom juveniles are more susceptible to infestations than adults due to their low immunity levels (Tariq et al. 2010; Khan et al. 2010; Zeryehun 2012; Nabi et al. 2014). This difference may be related to physiological status (gestation and breastfeeding stage) and malnutrition, making adults more susceptible to infestation and excreting more eggs than non-pregnant or nonbreast-feeder ones (Barry et al. 2002; Suarez et al. 2017). In addition, young animals are fed milk by their mothers until adulthood (Saidi et al. 2020), limiting their grazing exposure. Therefore they would be less infested, hence the finding of higher prevalence in adults than in young.

The higher infestation rates in Sahelian rears than in dwarf and mixed breeds indicate that they are more susceptible to gastrointestinal parasites than the other breeds. Their EPG burden is lower than that of the other breeds despite their higher infestation rates. The difference in EPG burden would be due to the limited infestation by infesting L3 larvae during grazing, as Sahelian goats were more commonly encountered in PDA1 and PDA2, which are characterized by a Sahelian climate. This hot and dry climate is not conducive to the development and survival of infesting L3 larvae.

Parasite burden in EPG were higher in PDA4 than in PDA1, PDA2, and PDA5. This outcome could be explained by the fact that free-grazing is the more common method of rearing in the dry season than in the wet season in PDA4, whereas in the other PDAs, during fieldwork in the wet season, animals were put on fixed or mobile stakes. This freedom, especially in the rainy season when conditions are favorable for the survival and translocation of the pre-parasitic stages of helminths, means that the animals would ingest enough infesting larvae on the grazing ground. As a result, the gastrointestinal burden of adult worms would be high and, consequently, a high rate of egg-laying expelled by the animals. On the other hand, the risk of infestation of the staked animals by a high burden of infesting larvae would be low even if they are fed fresh fodder. Furthermore, Trichirus spp eggs were not observed in PDA1 and PDA5 and Toxocara spp eggs in PDA1 and PDA2. This could indicate the absence of these parasites in these areas; helminthological autopsies could give more details.

Page $7 / 15$ 
The coprocultures showed that strongyles were represented by Haemonchus spp, Trichostrongylus spp, Oesophagostomum spp, Cooperia spp, Nematodirus spp, and Bunostomum spp. These results reveal that Haemonchus spp and Trichostrongy/us spp, are the most dominant strongyles species in the digestive tract of small ruminants as reported by reported by Salifou (1996) in South Benin. Similar observations had also been made in several tropical countries, Burkina Faso (Ouattara and Dorchies 2001; Belem et al. 2005), Middle Guinea (Barry et al. 2002), Côte d'Ivoire (Achi et al. 2003), Togo (Bastiaensen et al. 2003), Ethiopia (Sissay et al. 2007), Nigeria (Nwosu et al. 2007). This dominance would be explained by the fact that Haemonchus spp is very prolific and can lay up to 10000 eggs per day for several months (Raza et al. 2014). In addition, it acquires a faster resistance to synthetic antihelminthics compared to other strongyles species (Torres-Acosta et al. 2003). Haemonchus spp infection can cause severe anemia and hypoproteinemia, leading to depression, reduced productivity, and eventual animals' death. The disease tends to be more severe in the early stage, mainly when females breastfeed with weakened immune (Sissay et al. 2007). Trichostrongylus spp is not significant but is the most constant parasite, as its presence is annual. Large infestations of Trichostrongylus spp cause inappetence, diarrhea, rapid weight loss, and death of the animal may occur rapidly (Mahieu 2014). These parasites could be associated with diarrhea mentioned by goat breeders in Benin (Hounzangbé-Adoté 2001; Idrissou et al. 2017; Challaton 2020). A specific coprological study on goats presenting diarrhea will better evaluate the share of strongyles in the pathologies responsible for diarrhea in goats.

In the dry season, the proportion of Haemonchus spp in the fecal cultures decreased and was dominated by Trichostrongylus spp. Unlike Trichostrongylus spp, the Haemonchus spp population survives during the dry season partly as hypobiotic larvae (L4) in the mucosa of the abomasum (Salifou 1996). This halt in larval growth during the dry season will result in a high larval burden (L4) and a low burden of adult Haemonchus spp worms in the abomasum. This observation results in a drop in oviposition rate and low emission of eggs in the excrement. When conditions become favorable again in the rainy season, the hypobiotic $\mathrm{L}_{4}$ larvae will continue to develop into adults capable of laying eggs and consequently an increase in the number of eggs expelled in the feces. This finding proves the dominance of Haemonchus spp and Trichostrongylus spp larvae in fecal crops in the rainy and dry seasons, respectively. Haemonchus spp would thus preserve itself as a biological species in nature by using this strategy of increasing its prevalence on animals and inhibiting its development at the $\mathrm{L}_{4}$ larval stage, in particular, severe climatic periods of the year (Belem et al. 2005). Given the adverse effects of these two parasites on goats and the resistance to synthetic anthelmintics, special attention should be given to them in controlling gastrointestinal parasites of small ruminants.

\section{Conclusion}

This study shows that a wide range of gastrointestinal parasites infests goats reared under the traditional system in Benin. The coprological examinations revealed a strong presence of strongyles, Strongyloides spp, coccidian oocysts, and Moniezia spp, in order of importance, regardless of the Agricultural Development Poles, breed, sex, and age of the animals examined. The coproculture conducted revealed the presence of 5 genera of strongyles, namely: Haemonchus spp, Trichostrongylus spp, Oesophagostomum spp, Cooperia spp, and Bunostomum spp. The genera Haemonchus spp and Trichostrongylus spp were more frequent in all the Agricultural Development Poles. The importance of the economic losses (weight loss, reduction in the growth parameters, low milk production) caused by these gastrointestinal parasites should justify the implementation of a national program of animal deworming. The latter should be applied according to a schedule that considers the seasonal fluctuation of these parasites. Thus we suggest two treatments in PDA1, PDA2, and four PDA4 and PDA5: a periodic treatment of goats at the end of each dry and rainy season. Given the length of the wet season in PDA1 and PDA2, additional treatment in the middle of the rainy season would be desirable.

\section{Declarations}

\section{Acknowledgments}

The authors are grateful for the financial support of this work by the University of Abomey-Calavi through the "Programme des Fonds Compétitifs de Recherche III (PFCRIII)". The authors also thank the farmers for accepting to take samples from their animals.

\section{Funding}

This work was funded by the University of Abomey-Calavi through the "Programme des Fonds Compétitifs de Recherche III (PFCRIII)".

\section{Conflict of interest}

The authors declare that they have no conflict of interest.

\section{Ethics approval}

Neither this manuscript nor any part of the research has been published in any form and is not under review for publication elsewhere. All authors agree with the contents of the manuscript and its submission to the journal. The study was subject to collection of animal feces following a study protocol evaluated and approved by the research and extension committee and the responsible authorities where the work was conducted. The farmers gave their consent for the collection of feces. The collection of feces was carried out by veterinary paraprofessionals following the regulations and guidelines on animal husbandry and welfare.

\section{Consent to participate}

No human data were collected in this study.

\section{Consent for publication}

All authors agree with the content of the manuscript and its submission to the journal. 
The data analyzed in this study are available from the corresponding author on request.

\section{Code availability}

The data analyzed in this study are available from the corresponding author on request. The authors did not obtain a code for the data analyzed

\section{Authors' contributions}

Data collection in the field and laboratory analyses were done by CHALLATON Kétomon Pierre with the help of KIFOULY Aboudou Habirou. CHALLATON Kétomon Pierre processed and analyzed the data and interpreted the results. Then he wrote the first version of the manuscript. AKOUEDEGNI Coovi Guénolé and BOKO Kadoéito Cyrille supervised the field data collection and laboratory analysis. They also contributed to the critical revision of the manuscript. ALOWANOU Goué Géorcelin supervised the static analyses and revised the manuscript. HOUNDONOUGBO Pascal Venant contributed to the improvement of the scientific quality of the manuscript by proofreading the different versions. HOUNZANGBE-ADOTE Mawule Sylvie made a general supervision of the work.

\section{References}

1. Achi, Y.L., Zinsstag, J., Yeo, N., Dea, V., and Dorchies, P.H., 2003. Epidemiologie des helminthoses des moutons et des chevres dans la region des savanes du Nord de la Cote d'Ivoire, Revue de Médecine Vétérinaire, 154(3), 179-188.

2. Adomou C., Sinsin B., and Van der Maesen L.J.G., 2006. Phytosociological and chorological approaches to phytogeography: a meso-scale study in Benin, Systematics and Geography of Plants, 76, 155-178.

3. Aïtondji, A. L., Toyi, M.S.S., Kassa, B., and Sinsin, B., 2016. Caractéristiques floristiques, phytosociologiques et écologiques de la végétation des carrières au Bénin, Sciences de la vie, de la terre et agronomie, 3(2), 13- 24.

4. Alowanou, G.G., Adenilé, A.D., Akouèdegni, G.C., Bossou, A.C., Zinsou, F.T., Akakpo, G-C.A., Kifouly, H.A., Rinaldi, L., von Samson-Himmelstjerma, G., and Cringoli, G., 2021. A comparison of Mini-FLOTAC and McMaster techniques in detecting gastrointestinal parasites in West Africa Dwarf sheep and goats and crossbreed rabbits, Journal of Applied Animal Research. 49(1), 30-38. https://doi.org/10.1080/09712119.2021.1876703

5. Barry, A.M., Pandey, V.S., Bah, S., and Dorny, P., 2002. Etude épidémiologique des helminthes gastro-intestinaux des caprins en Moyenne Guinée, Revue d'élevage et de médecine vétérinaire des pays tropicaux, 55(2), 99-104.

6. Bastiaensen, P., Dorny, P., Batawui, K., Boukaya, A., Napala, A., and Hendrickx, G., 2003. Parasitisme des petits ruminants dans la zone périurbaine de Sokodé, Togo. II. Caprins, Revue d'élevage et de médecine vétérinaire des pays tropicaux, 56(1-2), 51-56.

7. Belem, A.M.G., Kaboré, A., and Bessin, R., 2005. Variations saisonnières des helminthes gastro-intestinaux chez la chèvre du plateau central du Burkina Faso, Revue d'élevage et de médecine vétérinaire des pays tropicaux, 58(1-2), 37-43.

8. Bosco A. 2014. The coprological diagnosis of gastrointestinal nematode infections in small ruminants (PhD Thesis, University Federico II of Naples, pp. 1-144)

9. Challaton, K.P., 2020. Etude épidémiologique des affections caprines et proposition des mesures de prophylaxie efficiente, (Point de thèse doctorale non publié, Université d’ Abomey-Calavi, Bénin. pp. 1-53)

10. Chartier, C., Lespine, A., Hoste, H., and Alvinerie, M., 2001. Les endectocides chez les caprins : pharmacologie, efficacité et conditions d'utilisation dans le contexte de la résistance aux anthelminthiques. Rencontres autour des Recherche sur Ruminan, 8, 181-186.

11. Cringoli, G., Rinaldi, L., Maurelli, M.P., and Utzinger, J., 2010. FLOTAC : new multivalent techniques for qualitative and quantitative copromicroscopic diagnosis of parasites in animals and humans, Nature Protocols, 5, 503-515. https://doi.org/10.1038/nprot.2009.235

12. Dagnachew, S., Amamute, A., and Temesgen, W., 2011. Epidemiology of gastrointestinal helminthiasis of small ruminants in selected sites of North Gondar zone, Northwest Ethiopia, Ethiopian Veterinary Journal, 15 (2), 57-68.

13. Dixit, P., Rao, M.L.V., Dixit, A.K., and Shukla, P.C., 2016. Prevalence of gastrointestinal parasites in goat kids in Jabalpur, Ruminant Science, 5(1), 39-42.

14. Dossa L.H., Wollny C., and Gauly M., 2007. Smallholders' perceptions of goat farming in southern Benin and opportunities for improvement, Tropical Animal Health and Production, 39, 49-57. https://doi.org/10.1007/s11250-006-4440-2

15. Faihun, A.M.L., Azando, E.V.B., Attakpa, E.Y., Akouèdegni, C.G., and Hounzangbe-Adote, M.S., 2017. Etude comparative de la charge parasitaire des petits ruminants et du guib harnaché dans quatre campements riverains à la forêt classée de Wari-Maro au Nord-Est du Bénin, Tropicultura, 35(1), 51-60.

16. FAOstat., 2021. Statistiques de l'Organisation des Nations Unies pour l'Alimentation et l'Agriculture, http://www.fao.org/faostat/fr/\#data/QA. Accessed 03 Oct 2021.

17. Githiori, J.B., Hogland, J., Waller, P.J. and Baker, R.L., 2004. Evaluation of anthelmintic properties of some plants used as livestock dewormers against Haemonchus contortus infection in sheep, Parasitology, 129, 245-53.

18. Gnanglè, C. P., Kakaï, R. G., Assogbadjo, A. E., Vodounnon, S., Yabi, J. A., and Sokpon, N., 2011. Tendances climatiques passées, modélisation, perceptions et adaptations locales au Bénin, Climatologie, 8, 27-40. https://doi.org/10.4267/climatologie.259

19. Gueguen, E., Leperre, P., Petit, H., Merlin, A., and Chartier, C., 2016. A coproscopical study of helminthosis in domestic ruminants (cattle, buffalo, goat) in Khammouane Province (Lao PDR), Revue de Médecine Vétérinaire, 167(11-12), 310-315.

20. Hounzangbé-Adoté, S., 2001. L'élevage face à la pharmacopée en médecine vétérinaire au sud du. Bénin. Bulletin de la recherche agronomique, Numéro 33 - septembre 2001. 
21. Idrissou, N-D., Ahounou, S.G., Tougan, U., Tamimou, M.I., Hounmanou, Y.M.G., Mensah, G.A., and Karim, I.Y.A., 2017. Morphometric and zootechnical characterization of dwarf goats in Northeastern Benin, International Journal of Agronomy and Agricultural Research, 11(3), 26-42.

22. Khan, M.N., Sajid, M.S., Khan, M.K., lqbal, Z., and Hussain, A., 2010. Gastrointestinal helminthiasis: prevalence and associated determinants in domestic ruminants of district Toba Tek Singh, Punjab, Pakistan. Parasitology Research, 107(4), 787-794. https://doi.org/10.1007/s00436-010-1931-x

23. Mahieu, M., 2014. Gestion du parasitisme gastro-intestinal des petits ruminants en zone tropicale humide (Thèse doctorale, Université de Lorraine, 2014. Français. NNT: 2014LORR0230.tel-01751239).

24. Mas-Coma, S., Valero, M.A., and Bargues, M.D., 2008. Effects of climate change on animal and zoonotic helminthiases, Revue Scientifique et Technique, 27(2), 443-457.

25. Nabi, H., Saeed, K., Shah, S.R., Rashid, M.I., Akbar, H., and Shehzad, W., 2014. Epidimiological study of gastrointestinal nematodes of goats in district swat, khyber pakhtunkhwa, Pakistan, Science International, 26(1), 283-286.

26. Ntonifor, H.N., Shei, S.J., Ndaleh, N.W., and Mbunkur, G.N., 2013. Epidemiological studies of gastrointestinal parasitic infections in ruminants in Jakiri, Bui Division, North West Region of Cameroon, Journal of Veterinary Medicine and Animal Health, 5(12), 344-352. https://doi.org/10.5897/JVMAH2013.0209

27. Nwosu, C.O., Madu, P.P., and Richards, W.S., 2007. Prevalence and seasonal changes in the population of gastrointestinal nematodes of small ruminants in the semi-arid zone of north-eastern Nigeria, Veterinary Parasitology, 144(1-2), 118-124. https://doi.org/10.1016/j.vetpar.2006.09.004

28. Ouattara, L., and Dorchies, P.H., 2001. Helminthes gastro-intestinaux des moutons et chèvres en zones sub-humide et sahélienne du Burkina Faso, Revue de Médecine Vétérinaire, 152, 165-170.

29. Paul, B.T., Biu, A.A., Ahmed, G.M., Mohammed, A., Philip, M.H., and Jairus, Y., 2016. Point prevalence and intensity of gastrointestinal parasite ova/oocyst and its association with Body Condition Score (BCS) of sheep and goats in Maiduguri, Nigeria, Journal of Advances in Parasitology, 3(3), 81-88. https://doi.org/10.14737/journal.jap/2016/3.3.81.88

30. Raza, M.A., Younas, M., and Schlecht, E., 2014. Prevalence of gastrointestinal helminths in pastoral sheep and goat flocks in the Cholistan desert of Pakistan, The Journal of Animal \& Plant Sciences, 24(1), 127-134.

31. Saidi, M., Stear, M.J., Elouissi, A., Mokrani, S., and Belabid, L., 2020. Epidemiological study of goat's gastrointestinal nematodes in the North West of Algeria. Tropical Animal Health and Production, 52(4), 1787- 1793. https://doi.org/10.1007/s11250-019-02193-6

32. Salifou, S. (1996). Nématodes et nématodoses du tube digestif des petits ruminants du Sud Bénin: Taxonomie, épidémiologie et les facteurs de variation, (Thèse Doctorale de Biologie Animale, Université d’Anta Diop de Dakar, Sénégal. pp. 1-171).

33. Schoenian, S., 2012. Periparturient Egg Rise-American Consortium for Small Ruminant Parasite Control. http://www.acsrpc.org/Resources/Topics/PPER.html

34. Sissay, M.M., Uggla, A., and Waller, P.J., 2007. Prevalence and seasonal incidence of nematode parasites and fluke infections of sheep and goats in eastern Ethiopia, Tropical Animal Health and Production, 39(7), 521- 531. https://doi.org/10.1016/j.smallrumres.2009.06.013

35. Suarez, V.H., Martínez, G.M., Viñabal, A.E., and Alfaro, J.R., 2017. Epidemiology and effect of gastrointestinal nematodes on dairy goats in Argentina, Onderstepoort Journal of Veterinary Research, 84(1), 1-5. https://doi.org/10.4102/ojvr.v84i1.1240.

36. Sylvia, O.U., Stephen, O.A., Oladeji, M.H., Abdulhakeem, A.A., Micheal, A.O., and Friday, E.U., 2015. Gastrointestinal helminth infections in a ruminant livestock farm in Abeokuta, South Western Nigeria, Annual Research \& Review in Biology, 8(4), 1-8.

37. Tariq, K.A., Chishti, M.Z., and Ahmad, F., 2010. Gastro-intestinal nematode infections in goats relative to season, host sex and age from the Kashmir valley, India, Journal of helminthology, 84(1), 93-97. https://doi.org/10.1017/S0022149X09990113

38. Terefe, D., Demissie, D., Beyene, D., and Haile, S., 2012. A prevalence study of internal parasites infecting Boer goats at Adami Tulu agricultural research center, Ethiopia, Journal of Veterinary Medicine and Animal Health, 4(4), 12-16. https://doi.org/10.5897/JVMAH11.046

39. Thienpont, D., Rochette, F., and Vanparijs, O.F.J., 1995. Le diagnostic des verminoses par examen coprologique. 2è édition, Jansen Research Foundation Beerse, Belgique, juin 1995. pp. 205

40. Tidjani, M.A., and Akponikpe, P.B.I., 2012. Évaluation des stratégies paysannes d'adaptation aux changements climatiques: cas de la production du maïs au Nord-Bénin, African crop science journal, 20, 425-441.

41. Torres-Acosta, J.F.J., Dzul-Canche, U., Aguilar-Caballero, A.J., and Rodrıguez-Vivas, R.I., 2003. Prevalence of benzimidazole resistant nematodes in sheep flocks in Yucatan, Mexico, Veterinary Parasitology, 114(1), 33-42. https://doi.org/10.1016/S0304-4017(03)00076-1

42. Van Wyk, J.A., and Mayhew, E., 2013. Morphological identification of parasitic nematode infective larvae of small ruminants and cattle: A practical lab guide, Onderstepoort Journal of Veterinary Research, 80(1), Art. \#539, 14 pages. https://doi.org/10.4102/ojvr.v80i1.539

43. Waller, P.J., 2006. From discovery to development: current industry perspectives for the development of novel methods of helminth control in livestock. Veterinary Parasitology, 139(1-3), 1-14. https://doi.org/10.1016/j.vetpar.2006.02.036

44. Wesongah, J.O., Chemuliti J., Wesonga, F.D., Wanjala, K., Munga, L., Ngare, P., and Murilla, G.A., 2005. Prevalence of parasitic infections in small ruminants in a pastoral community in Narok district, Kenya, Bulletin of Animal Health and Production Journal, 53(4), 218-225.

45. Ye, A., 2012. Contribution à la connaissance des pathologies des petits ruminants dans trois communes du Houet (Dandé, Padema et Satiri) (Mémoire d'Ingénieur de Développement Rural, Université Polytechnique de Bobo-Dioulasso, Burkina Faso. pp. 1-63).

46. Zeryehun, T., 2012. Helminthosis of sheep and goats in and around Haramaya, Southeastern Ethiopia, Journal of Veterinary Medicine and Animal Health, 4(3), 48-55. https://doi.org/10.5897/JVMAH12.0014

\section{Figures}




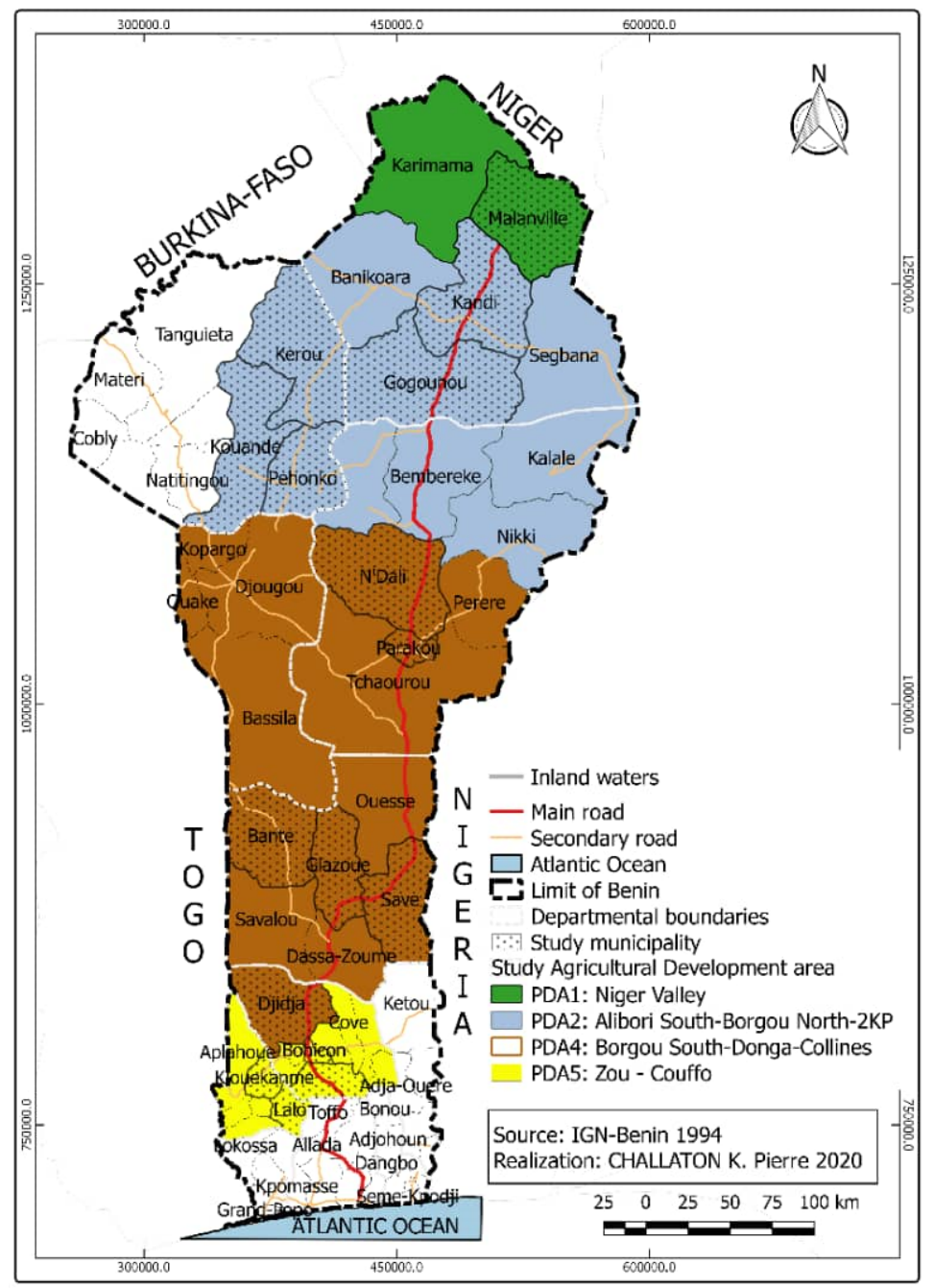

\section{Figure 1}

Location of the study area

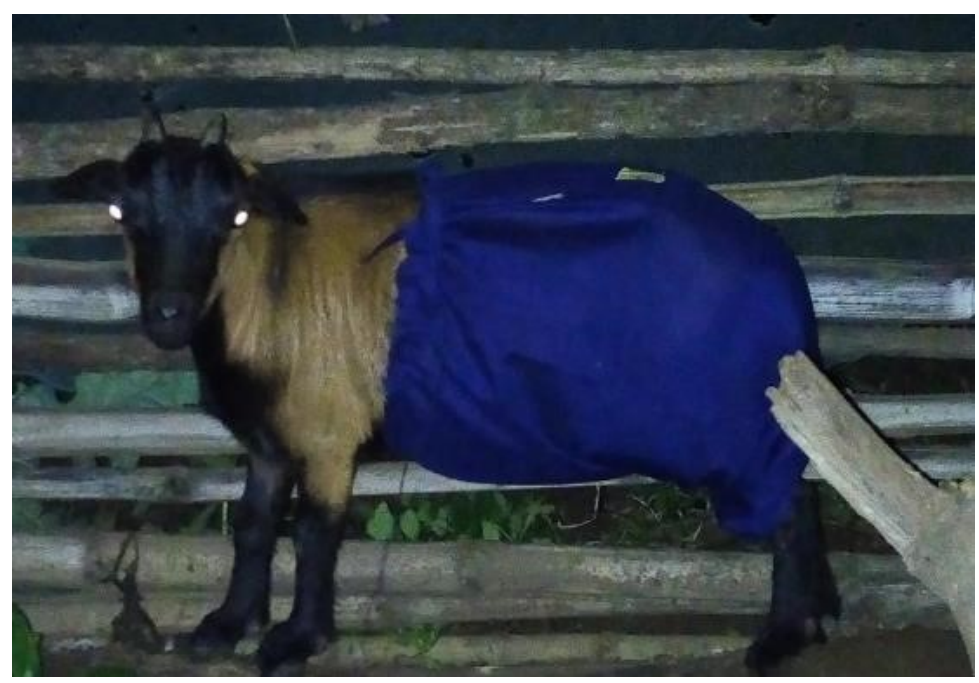

Figure 2

Wearing of panties 


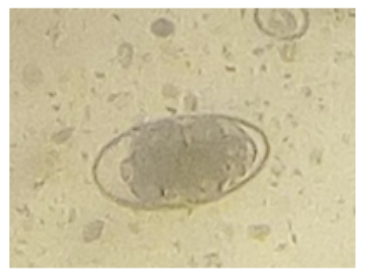

a- Strongyles egg

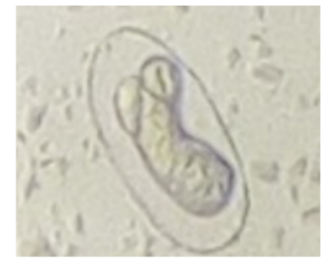

b-Strongyloides spp egg

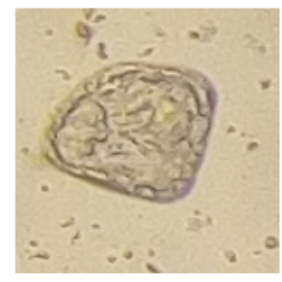

c-Moniezia spp egg

Figure 3

Eggs of Strongyles, Strongyloides spp, and Moniezia spp

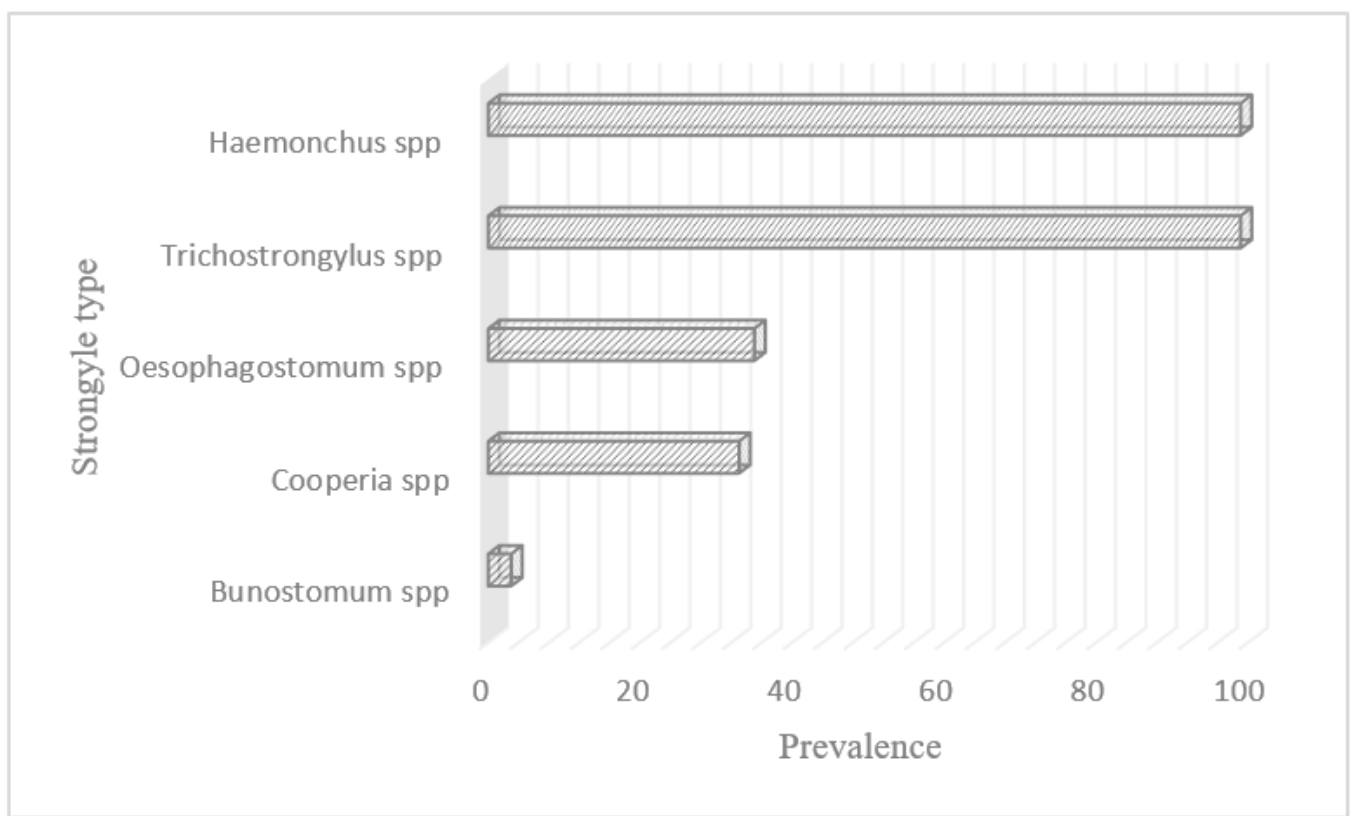

Figure 4

Prevalence of different strongyles species

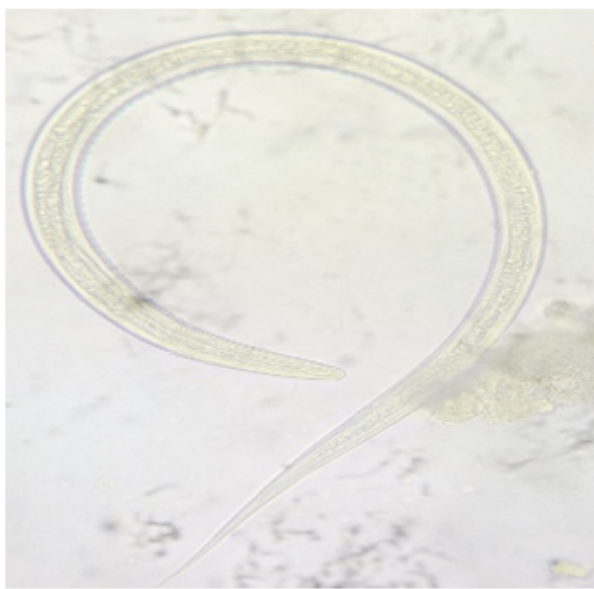

a- Haemonchus spp larva

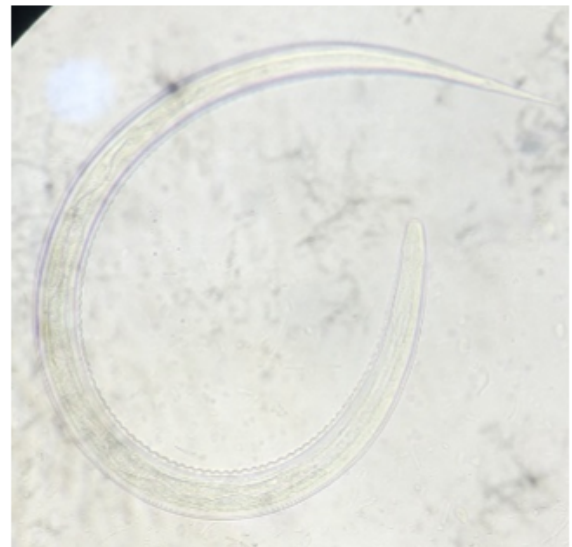

b-Trichostrongvlys spp larva

Figure 5

Larvae of Haemonchus spp and Trichostrongylys spp 


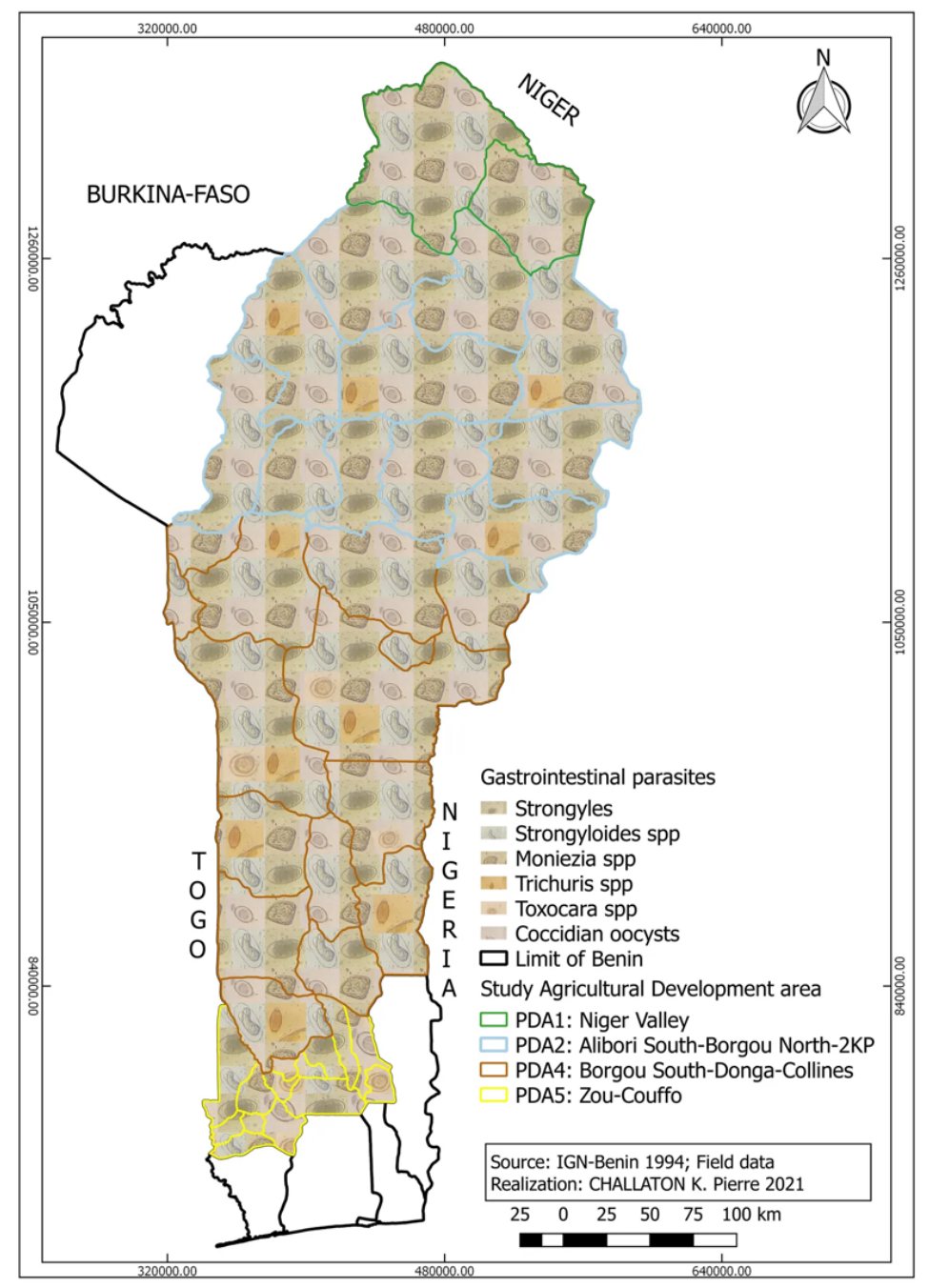

Figure 6

Distribution of gastrointestinal parasites of goats in Benin 


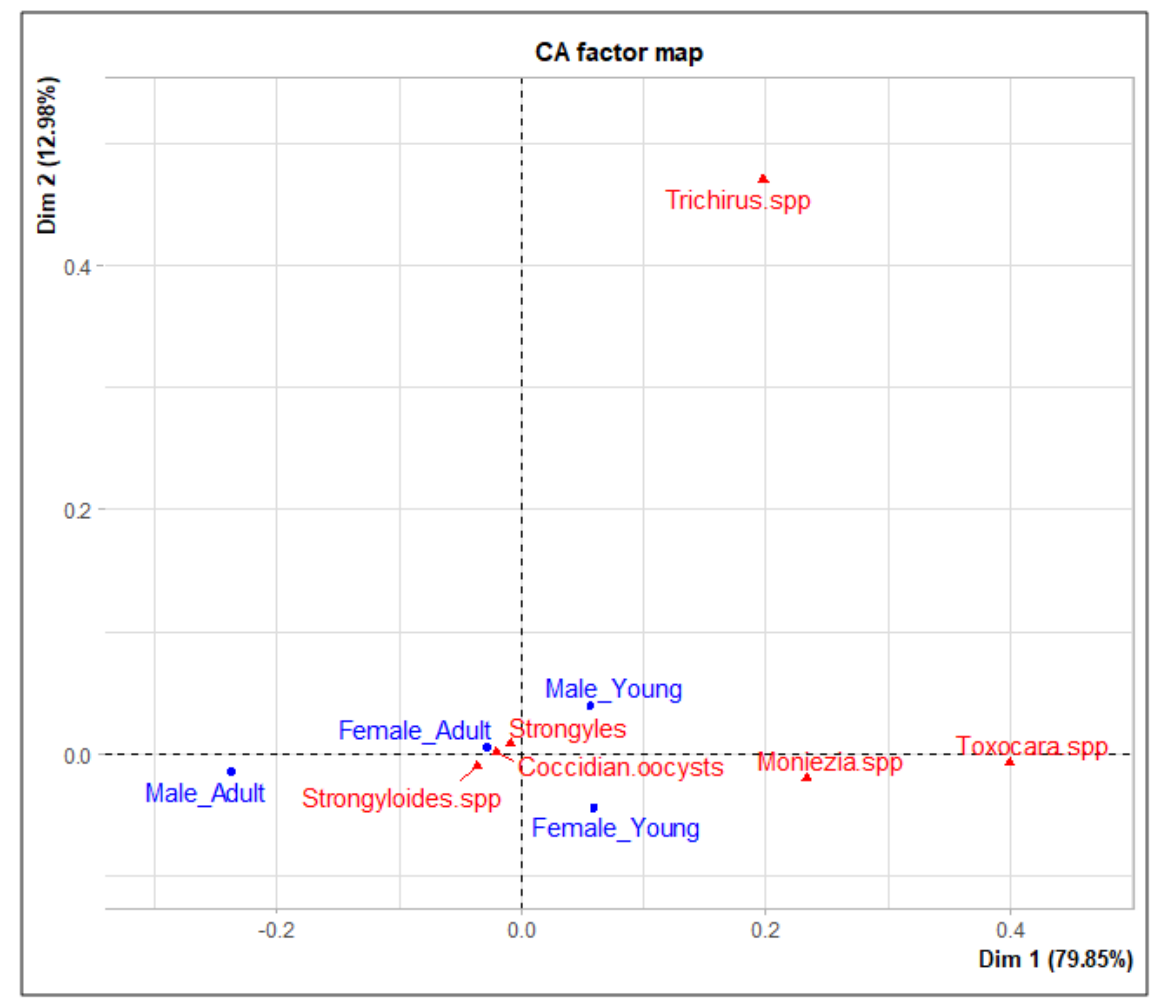

Figure 7

Projection of the results of the CFA of parasites and sex-age on the first two factorial axes

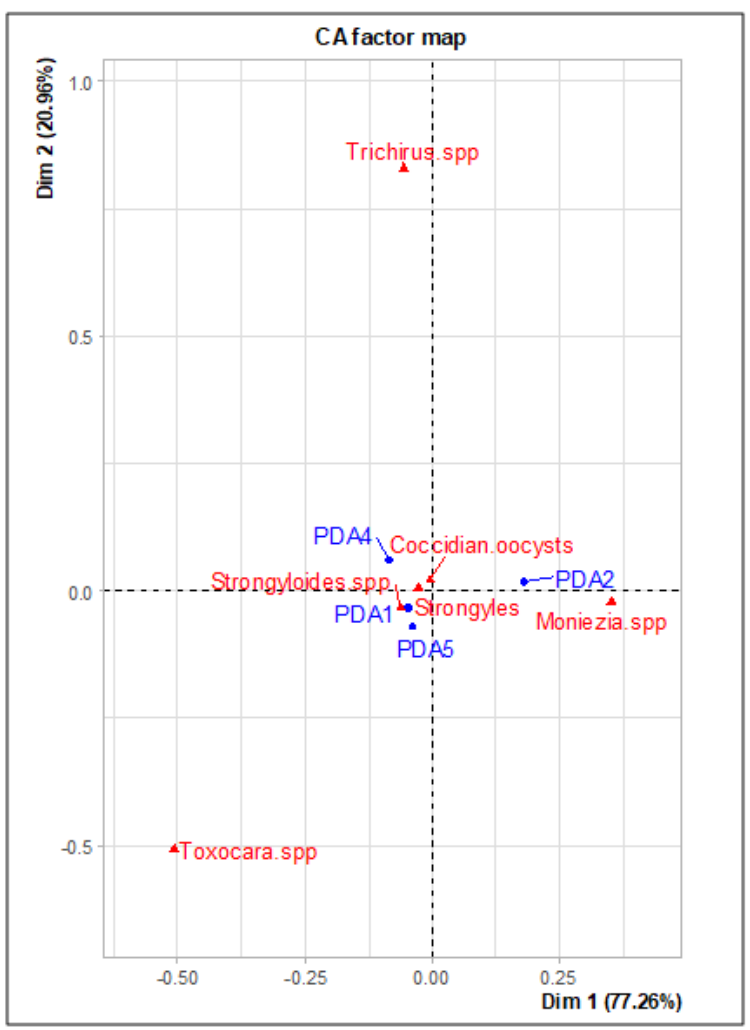

Figure 8

Projection of the results of the CFA of parasites and PDA on the first two factorial axes 


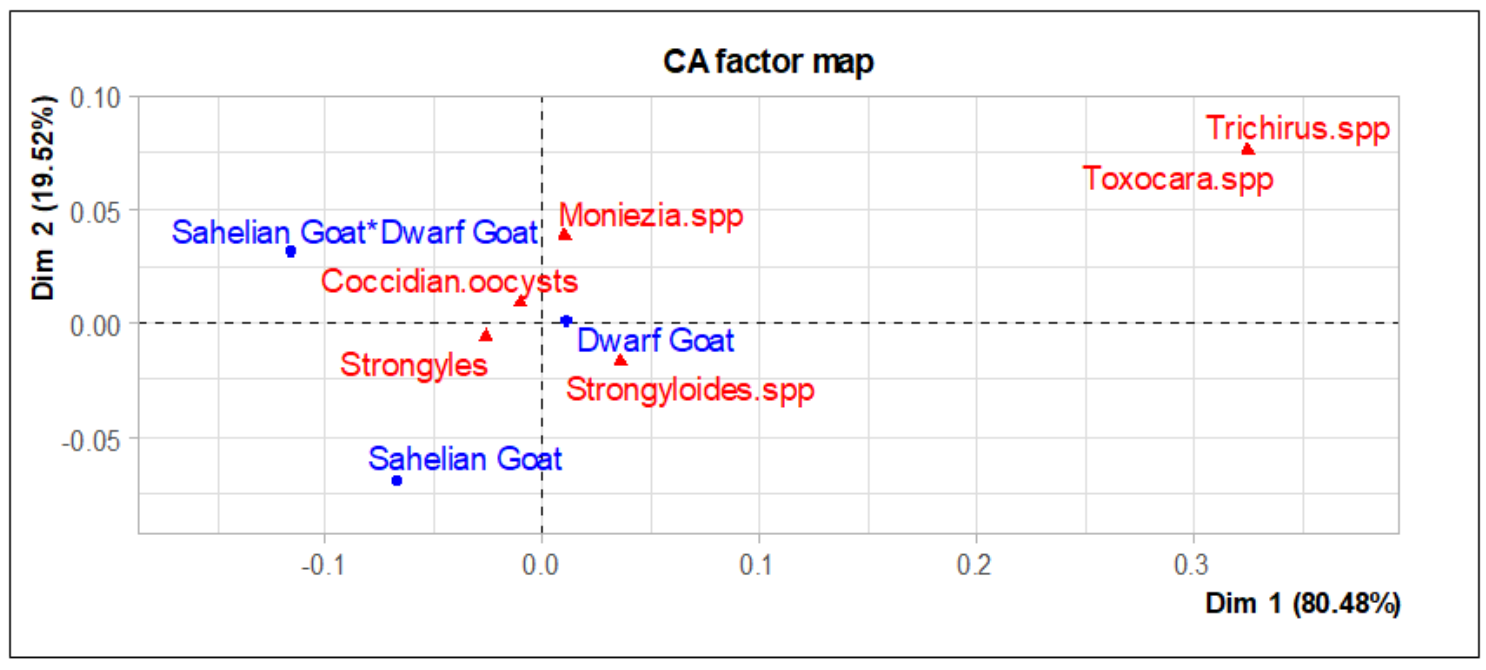

Figure 9

Projection of the results of the CFA of parasites and race on the first two factorial axes 